\title{
Primary Intracranial Ewing's Sarcoma (Peripheral Primitive Neuroectodermal Tumour of Parietal Bone) with Spinal and Pelvic Metastasis in a Young Female Child: Rare Case Report and Review
}

\section{Sarcoma de Ewing primitivo intracraniano (tumor neuroectodérmico primitivo periférico) com metástase espinhal e pélvica em criança: relato de caso raro e revisão}

\author{
Mahendran Jolarpettai Venugopal ${ }^{1}$ Aravinth Kumar Ashok ${ }^{1}$ Sneha Chitra Balasubramanian ${ }^{1}$ \\ Selvaraj Ramakrishnan ${ }^{1}$ \\ ${ }^{1}$ Institute of Neurosurgery, Madras Medical College, Chennai, Tamil \\ Nadu, India \\ Arq Bras Neurocir 2016;35:334-343. \\ Address for correspondence Mahendran J. Venugopal, PhD, Institute \\ of Neurosurgery, Madras Medical College, E.V.R Periyar Salai, Park \\ Town, Opp. Central Railway Station, Chennai 600003, Tamil Nadu, \\ India (e-mail: mahendranvenugopal@gmail.com).
}

\author{
Abstract \\ Keywords \\ - primary intracranial \\ Ewing's sarcoma CD \\ 99 Positive \\ - spinal and pelvic \\ metastasis \\ - excision of cranial and \\ spinal lesions \\ - primary spinal \\ stabilization \& mesh \\ cranioplasty \\ - post-operative \\ radiotherapy \& \\ chemotherapy \\ - one year follow up \\ without recurrence
}

Introduction The Peripheral Primitive Neuroectodermal Tumour (PPNET)/Ewing's sarcoma family tumor (ESFT) group is a recently redefined term which includes all small round cell tumors of bone, soft tissue, and nerve with a common neuroectodermal origin. These highly aggressive pediatric soft tissue tumors occur less frequently in the craniospinal axis. Primary cranial lesion associated with spinal and pelvic metastasis is a rare presentation.

Clinical Presentation A 9-year old girl was hospitalized with features of progressive increase in intracranial pressure with quadriparesis. The patient had $4 / 5$ quadriparesis with bilateral papilledema. Brain MRI showed a large, hetero intense, contrast enhancing right parietal bony lesion infiltrating the dura with mass effect over the brain. Brain CT showed bony expansion and multiple calvarial lytic lesions. MRI cervical spine revealed collapsed fourth cervical vertebral body with extensive paravertebral and paraspinal soft tissue components with cord compression. Metastatic workup revealed a lytic lesion in the left iliac bone and left lung. The patient underwent a surgically challenging C4 corpectomy with cage fixation followed by craniotomy and excision of parietal bony lesion with titanium mesh cranioplasty in the same sitting. Histopathology revealed pPNET and was confirmed by CD99 positivity.

Conclusion This rare multiple site tumor presentation was carefully planned and effectively managed by a combined single-stage surgical approach involving total excision of primary parietal bone and metastatic cervical spine tumors with primary received

December 14, 2015

accepted

February 2, 2015

published online

May 13, 2016
Copyright $\odot 2016$ by Thieme-Revinter

Publicações Ltda, Rio de Janeiro, Brazil
License terms

10.1055/s-0036-1582429. ISSN 0103-5355.

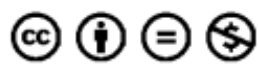




\section{Resumo}

\section{Palavras-chave}

- sarcoma de Ewing primário intracraniano

- CD99 positivo

- metástase

- espinhal e pélvica

- excisão de lesões craniais e espinhais

- estabilização primária da espinha

- cranioplastia com malha

- radioterapia e químioterapia

- pós-operatória

- acompanhamento de um ano titanium mesh cranioplasty and cervical spine stabilization, followed with radiotherapy and chemotherapy, which resulted in good recovery and improved the overall prognosis for the patient.

Introdução O grupo 'tumor neuroectodérmico primitivo periférico (pPNET) / tumor da família dos sarcomas de Ewing (ESFT)' é um termo recentemente redefinido o qual inclui todos as pequenas arredondadas células de tumor ósseo, tecidos moles e nervos com origem neuroectodérmica comum. Estes tumores pediátricos de tecido mole altamente agressivos ocorrem com menor frequência no eixo cranioespinal. Lesões primárias do crânio associadas a metástase espinhal e pélvica são raras.

Relato de Caso Criança de 9 anos de idade hospitalizada com fraturas e pressão intracraniana crescente com quadriparesia. A paciente teve $4 / 5$ de quadriparesia com papiledema bilateral. RM do cérebro por contraste mostrou uma lesão óssea parietal direita extensa e hétero-intensa infiltrando a dura-máter com efeito maciço sobre o cérebro. TC do cérebro mostrou expansão óssea e múltiplas lesões líticas na calota craniana. RM da espinha cervical revelou colapso da quarta vertebra cervical com componentes paravertebral e paraespinal de tecido mole com compressão da medula. Workup metastático revelou uma lesão lítica no ilíaco esquerdo e pulmão esquerdo. A paciente foi submetida a difícil corpectomia da C4 com fixação de cage seguida de craniotomia e excisão da lesão parietal óssea com cranioplastia com malha de titânio na mesma posição. Histopatologia revelou PPNET, confirmada por positividade de CD99. Conclusão Este raro caso com apresentação de múltiplos tumores foi cuidadosamente planejado e eficazmente conduzido por acessos cirúrgicos combinados em fase única envolvendo excisão total do osso parietal primário e tumores metastáticos da espinhal cervical com cranioplastia com malha de titânio e estabilização da espinha cervical, seguida de radioterapia e quimioterapia, resultando em boa recuperação e melhora no prognóstico geral da paciente.

\section{Introduction}

CNS Primitive Neuro Ectodermal Tumour (PNET) refers to a heterogeneous group of embryonal tumors that occur predominantly in children and adolescents and show aggressive clinical behavior. They may be phenotypically poorly differentiated, or show divergent differentiation along neuronal, astrocytic, and ependymal lines. This group of peripheral primitive neuro ectodermal tumors has been recently redefined on the basis of cytogenetic, molecular genetics, and histopathologic characteristics. ${ }^{1,2}$

Most small round cell tumors previously classified as Ewing's sarcoma are now being classified as peripheral PNET (pPNET). The cytogenetic abnormality in Ewing's sarcoma and peripheral PNET have supported a common neuro ectodermal origin.

The term central-PNET ( $c$ PNET) has been used to describe tumors arising from the brain and spinal cord, of which Medulloblastoma is the best example.

Small round blue cell non CNS tumors from the bone and soft tissue arising from the germinal epithelium have been classified as pPNET/ Ewing's Sarcoma Family Tumours (ESFTs), which includes Ewings sarcoma of bone, extra osseous Ewing's sarcoma, pPNET (peripheral neuroepithelioma), and Askins tumor. ${ }^{1,3}$
Although traditionally known to arise from the soft tissue and bone, rare cases have been occasionally reported in the cranial-spinal axis, which includes the brain, spine, meninges, cranial, and spinal nerve roots. A literature review shows that less than 15 such cases have been reported so far. All of which fall into one of the two categories: isolated duralbased lesion mimicking a meningioma or a diffuse involvement of cranial and spinal leptomeninges meninges in the absence of a primary intracranial and meningeal tumor.

Occurrence of the primary lesion at cranial site with metastasis at cervical spine and pelvis has rarely been reported. Complete resolution of the multiple lesions after treatment on one-year follow-up is another rare occurrence; hence, the importance of this case report.

\section{Clinical Presentation}

We report on a 9-year-old girl who was hospitalised with features of progressive increase in intracranial pressure with quadriparesis (-Fig. 1).

Upon examination, the patient had $4 / 5$ quadriparesis with bilateral papilledema.

MRI of the cervical spine revealed extensive paravertebral and paraspinal soft tissue component, which was hypo intense in $\mathrm{T} 1$, hyper intense in $\mathrm{T} 2$, with homogenous contrast 


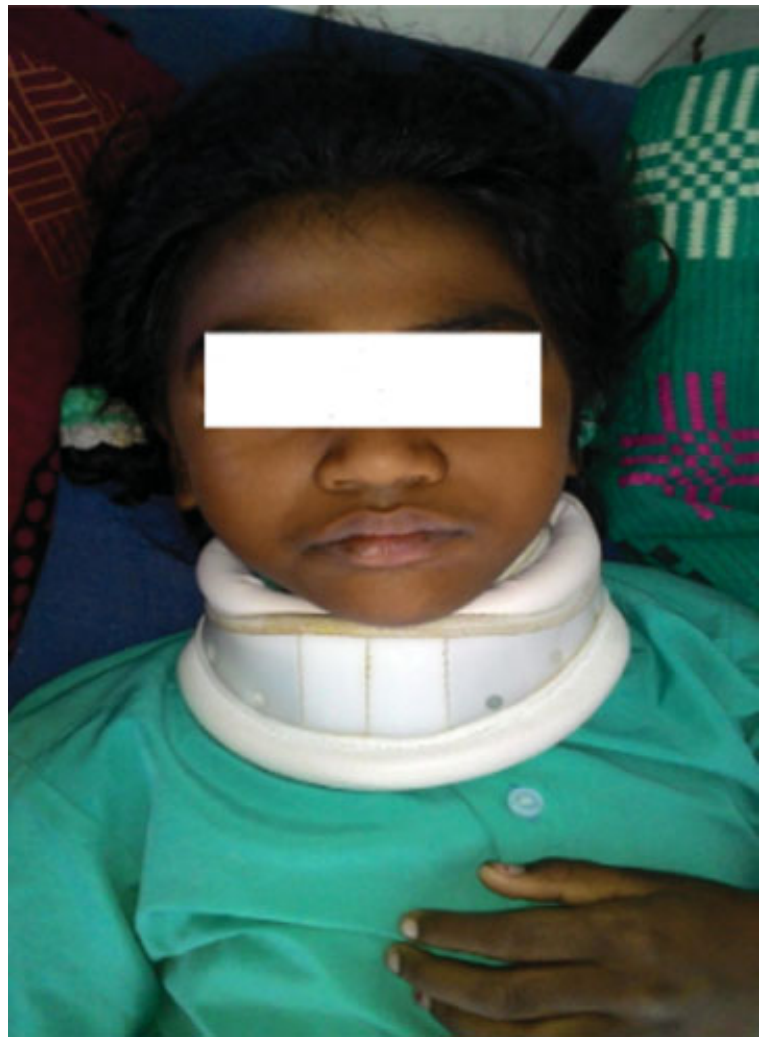

Fig. 1 Nine-year-old girl with features of progressive increase in intracranial pressure with quadriparesis.

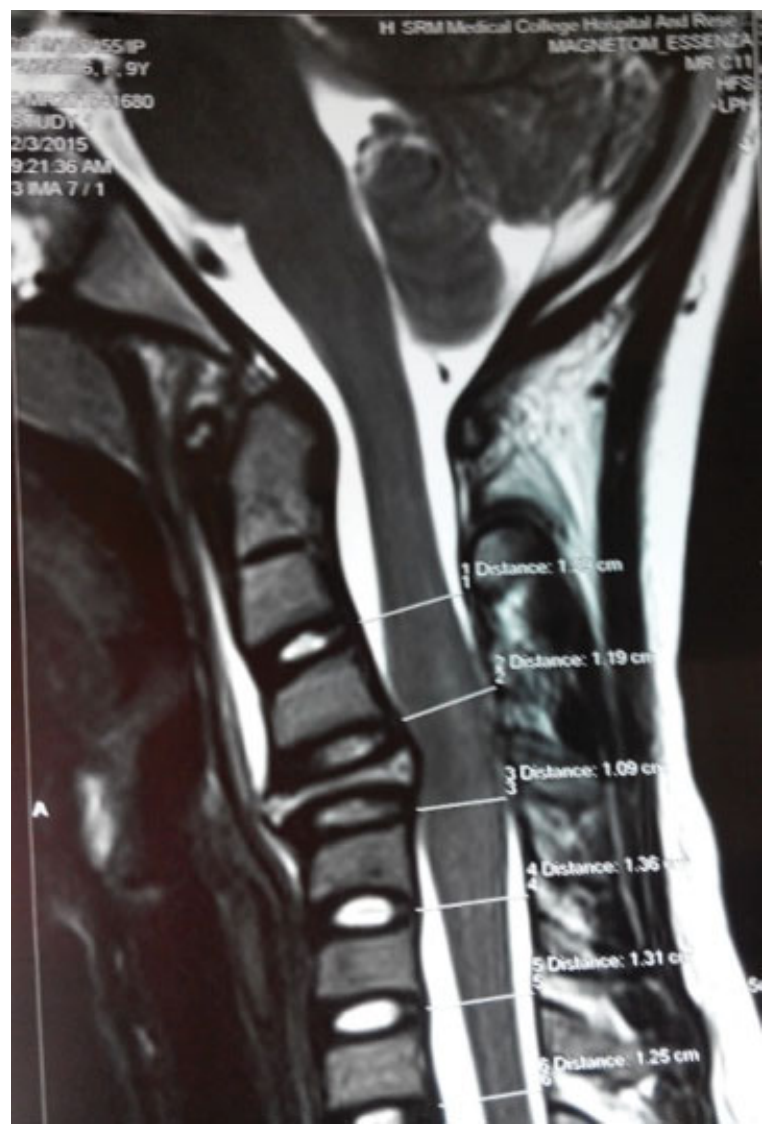

Fig. 3 Collapse Dc4 vertebral body.

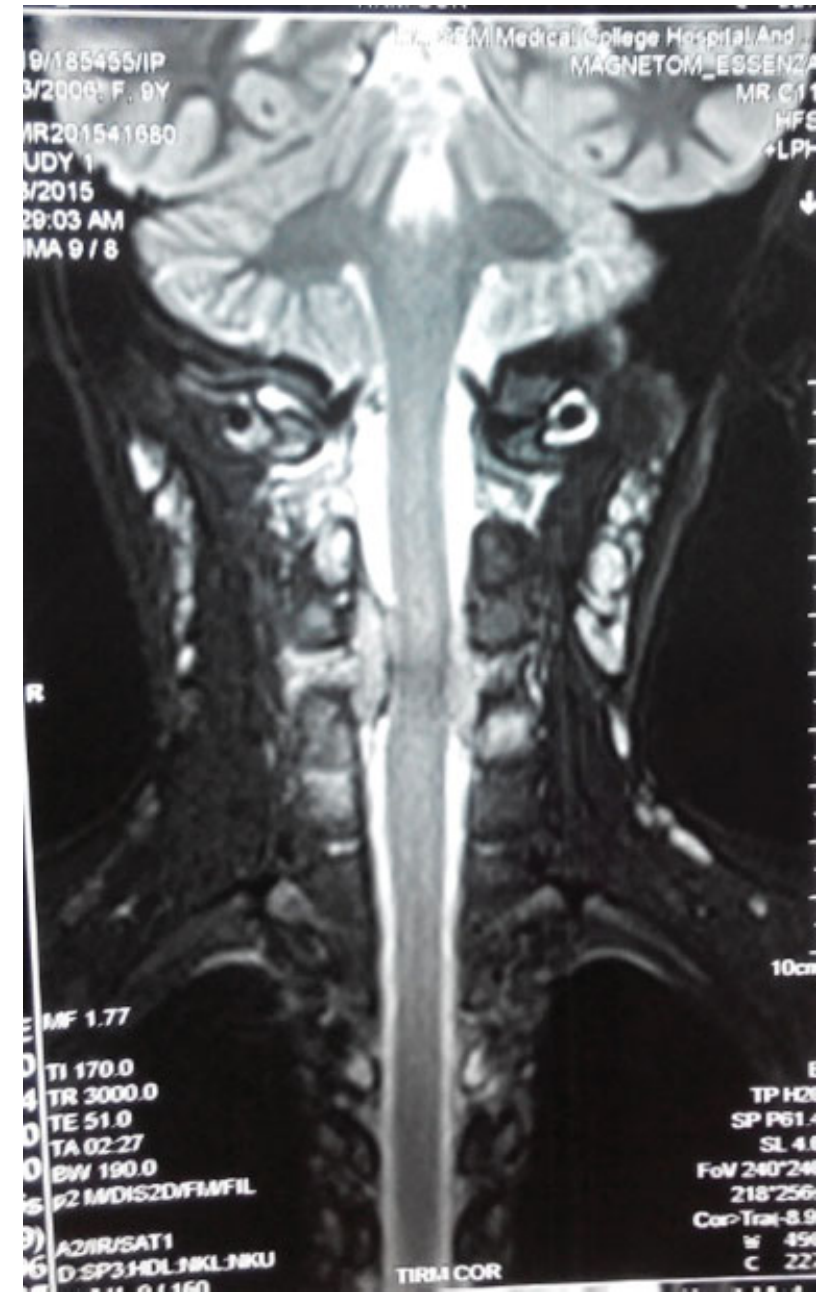

Fig. 2 Paravertebral soft tissue.

enhancement (-Fig. 2), and a completely collapsed fourth cervical vertebral body with marrow changes and significant cord compression (-Fig. 3 ). The rest of the thoracic and lumbar spine was normal.

She underwent brain CT, which showed a large lobulated and irregular hyper dense contrast-enhancing lesion in the right parietal region with bony expansion and lytic changes, dural infiltration, and mass effect over the brain (-Fig. 4). Multiple lytic lesions were also noted in the rest of the skull (-Fig. 5).

Brain MRI revealed well-defined hetero intense broad based lobulated lesion infiltrating the dura with mass effect (-Fig. 6A, B, and 7).

Metastatic work-up revealed a lesion in the left iliac bone (-Fig. 8A). Chest CT showed a small nodule in the left lunglower lobe basal region (-Fig. $\mathbf{8 B}$ ). Abdomen scans were normal. The rest of the long bones were also normal.

Child was worked up for surgery and, after careful consideration of the clinical condition of the patient and the imaging studies, we decided to proceed with a single-stage procedure for both the cranial and spinal lesions, along with stabilization of the cervical spine and mesh cranioplasty for the skull. 


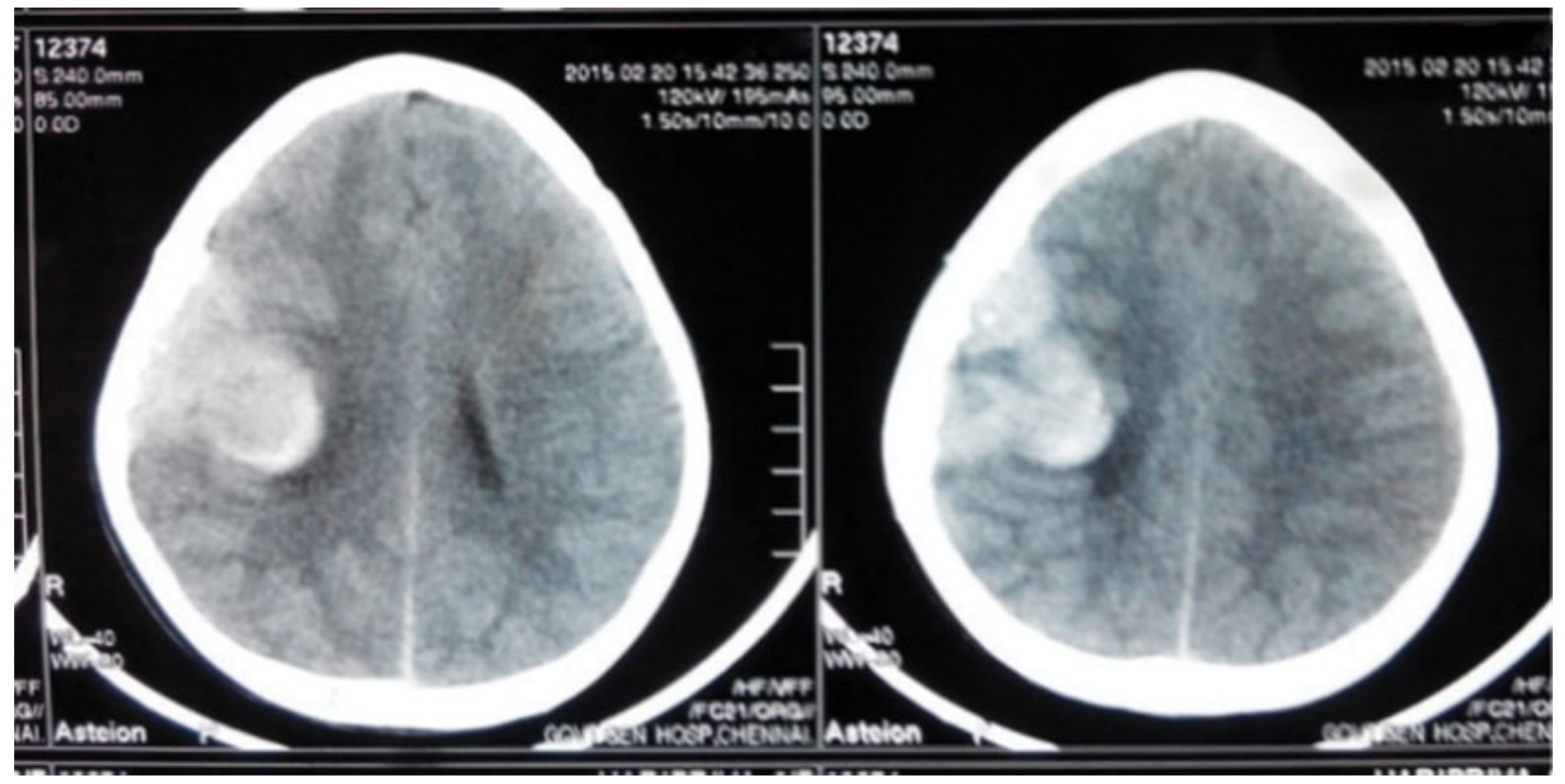

Fig. 4 Hyperdense parietal lesion.

We performed C4 corpectomy and titanium cage fixation by an anterior cervical approach. The vertebral body was deformed and friable granulation tissue could be seen surrounding the collapsed body, which was excised completely (-Fig. 9).

Next, we surgically exposed the right side parietal cranial lesion. The tumor had infiltrated the bone. Extensive soft tissue component was present. We encountered a highly vascular lesion, greyish white with dural breach and an intradural lobulated reddish mass involving the brain parenchyma, which we excised completely along with the involved dura and bone and performed titanium mesh cranioplasty (-Fig. 10).

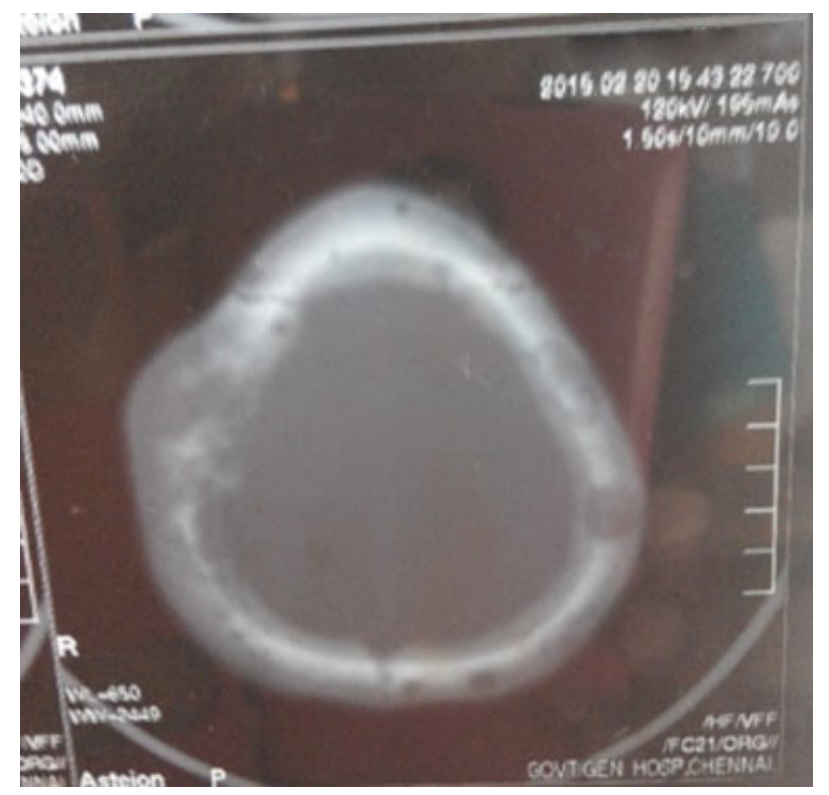

Fig. 5 Calvarial lytic lesions.
The child tolerated the procedures well and there were no postoperative complications. Her power recovered completely and there was no other neurological deficit.

Histopathology of the tumor was reported as peripheral PNET (Ppnet) belonging to the Ewing's sarcoma family. We then noted fragments of bone and cartilage surrounded by small round blue cells in a fibrocollagenous background with increased apoptosis (-Fig. 11).

Immunohistochemistry was positive for CD99 (-Fig. 12) and negative for vimentin and CD45.

Bone marrow biopsy was negative for metastatic deposits.

The child underwent focal Radiotherapy (300cGy), which was followed by twelve cycles of chemotherapy (cisplatin, cyclophosphamide, and vincristine). Post-radiation and chemotherapy, the child recovered fully and is doing well (-Fig. 13). She has been undergoing periodic follow-up with no new lesions in one year follow-up (-Fig. 14).

She underwent full body radioisotope scintigraphy after one year (-Fig. 15).

\section{Discussion}

Peripheral PNETs/ESFTs most commonly develop in the second decade of life and show a slight male predominance. Signs and symptoms of pPNETs typically include a mass and/ or pain at the primary site. ${ }^{1-4}$

Bone pPNETs most often arise in the long bones of the extremities as metaphyseal or diaphyseal lesions.

Soft tissue pPNETs, in turn, are found most commonly in the chest wall and paravertebral extradural locations, although they are also found in the extremities, the retro peritoneum, and occasionally in association with large peripheral nerves, such as the brachial plexus or sciatic nerve. These tumors are highly aggressive and progress rapidly with 


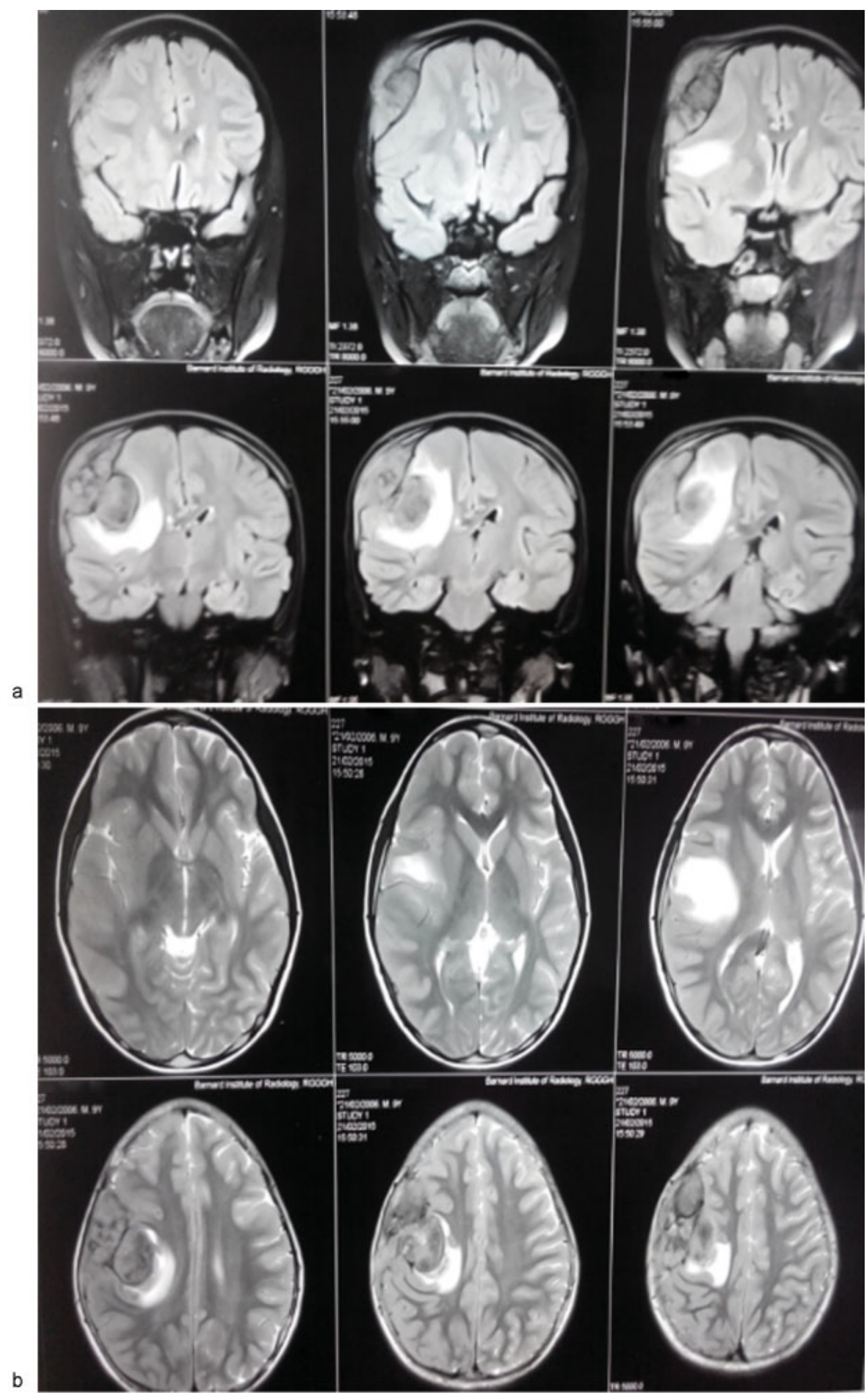

Fig. 6 (A) Coronal MRI. (B) Axial MRI.

metastases most common to the lung, bone, and bone marrow.

Primary involvement of the craniospinal vault by ESFTs are rare occurrences. Isolated CNS involvement of the
ESFTs must be differentiated from metastasis of ESFTs to the CNS. Most CNS ESFTs are extra-axial mass lesions involving the spinal or intracranial dura matter. When presenting in the skull, these tumors can extend to the 


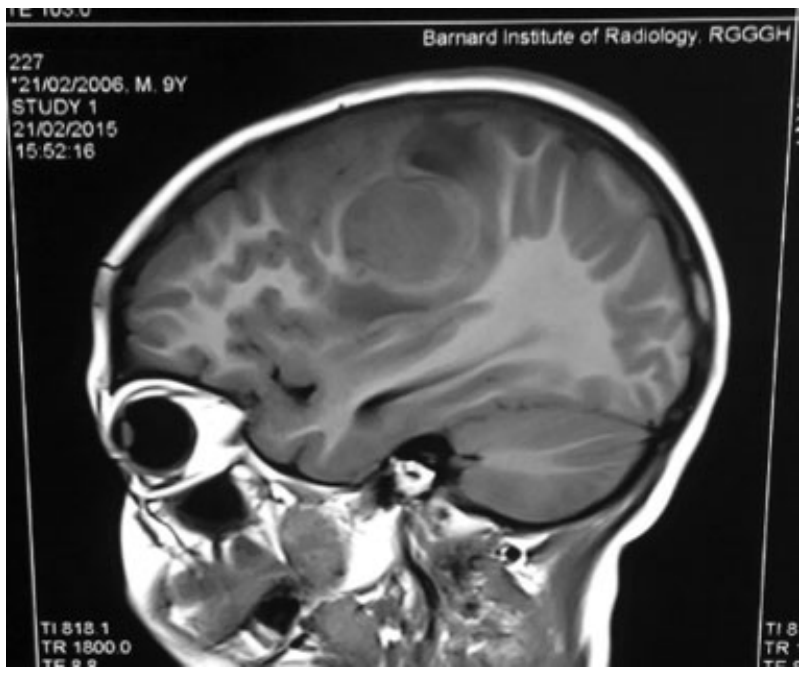

Fig. 7 Sagital MRI.

extradural space and cause a mass effect on the underlying brain parenchyma, although dural invasion and parenchymal involvement is rare. The masses are usually circumscribed with conspicuous contrast enhancement, often mimicking meningiomas. ${ }^{1,2}$

Differentiating between pPNETs and cPNETs is of clinical importance, as correct pathologic diagnoses are required for accurate prognostication. Appropriate treatment provides a 5year progression-free survival for approximately one half to two thirds of patients with localized ESFTs. Examining CD99 expression and assaying for the presence of a EWS/ETS gene fusion are reliable ways of distinguishing pPNETs from cPNETs.

Another defining characteristic of pPNETs/ESFTs is their expression of the MIC2 gene product. The cell surface glycoprotein CD99, the product of the MIC2 gene, is detected in most pPNET cases, and its expression is highly reliable as a positive marker for this tumor group.

CD99 immunopositivity has been detected in other small round cell tumors, but staining patterns in these cases are

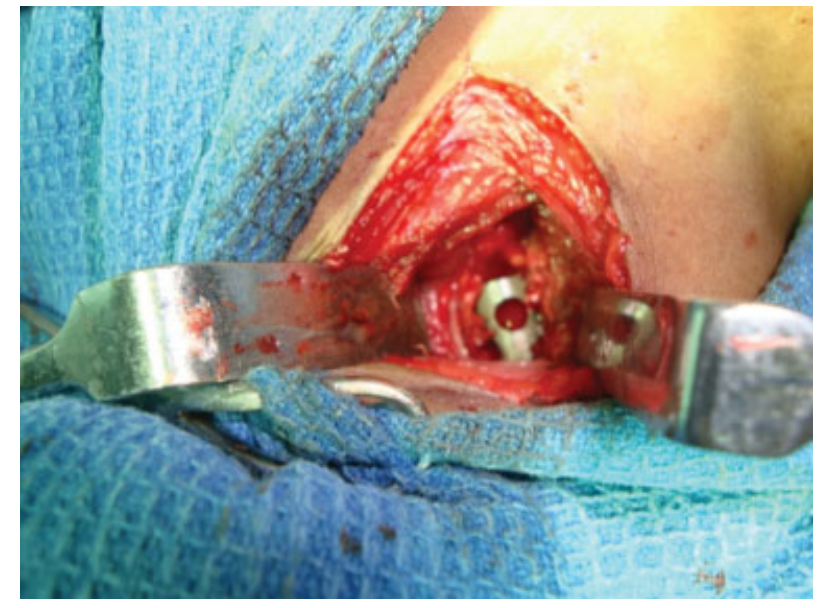

Fig. 9 Titanium cage at corpectomy site.

often cytoplasmic, rather than the distinct membranous staining typical of pPNETs/ESFTs.

Optimal combined modality treatment, which includes surgical resection, chemotherapy, and radiotherapy differs for pPNETs and cPNETs.

For Ewing's family tumors, the current chemotherapy regimens include the use of ifosfamide and etoposide in addition to vincristine, doxorubicin, cyclophosphamide, and actinomycin D.

For cPNETs, a combination of vincristine and cisplatin with lomustine or with cyclophosphamide have proven to be effective. $^{3,4}$

\section{Conclusion}

The patient had an unusual presentation, with primary in the cranial bone with cervical spine and pelvic and suspicious lung secondaries, in contrast to the usual long bone and soft tissue Ewing's tumors.
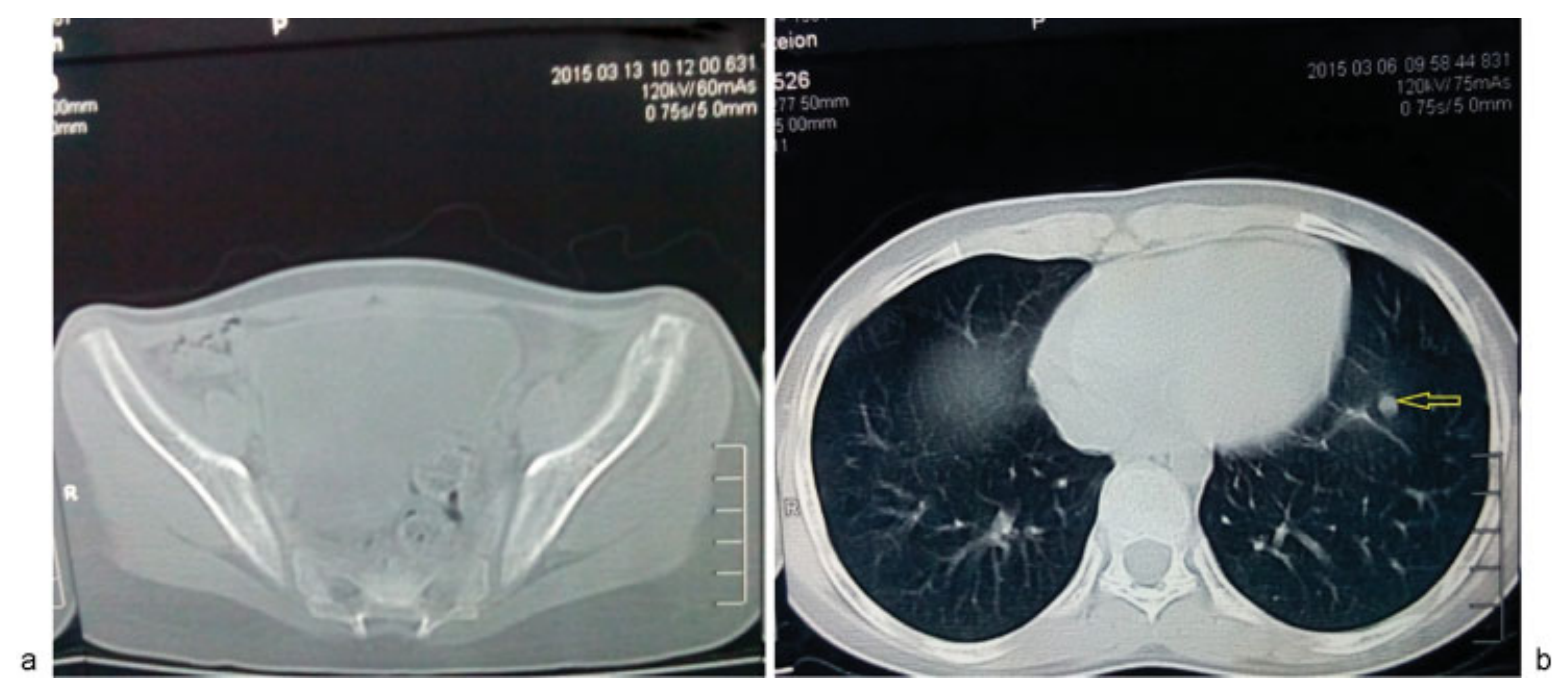

Fig. 8 (A) Lytic left illiac lesion. (B) Left lung basal secondary. 


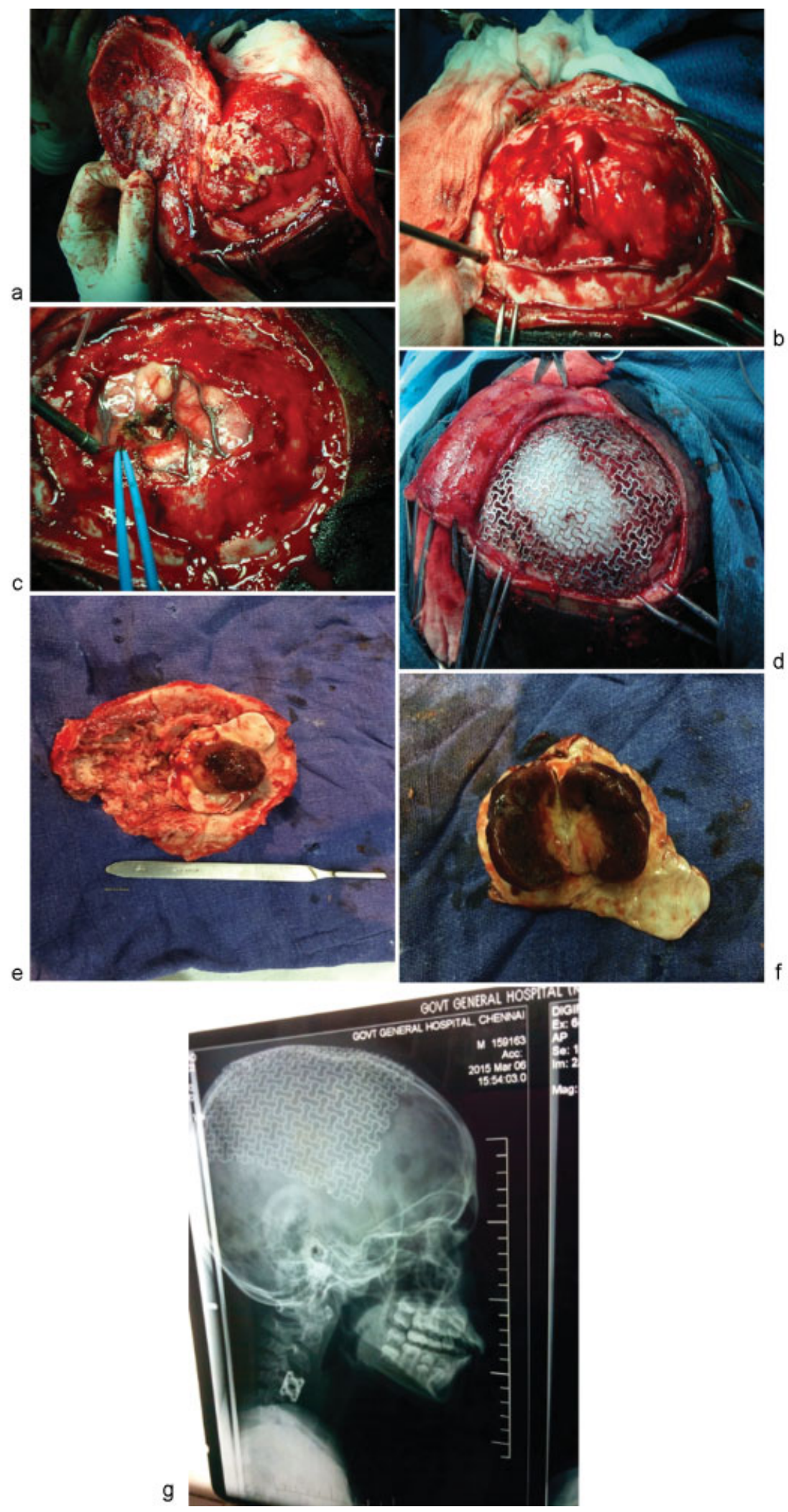

Fig. 10 (A-F) Intra-op \& post-op pictures; (G) a-post op X-ray with mesh and cervical cage. 
a

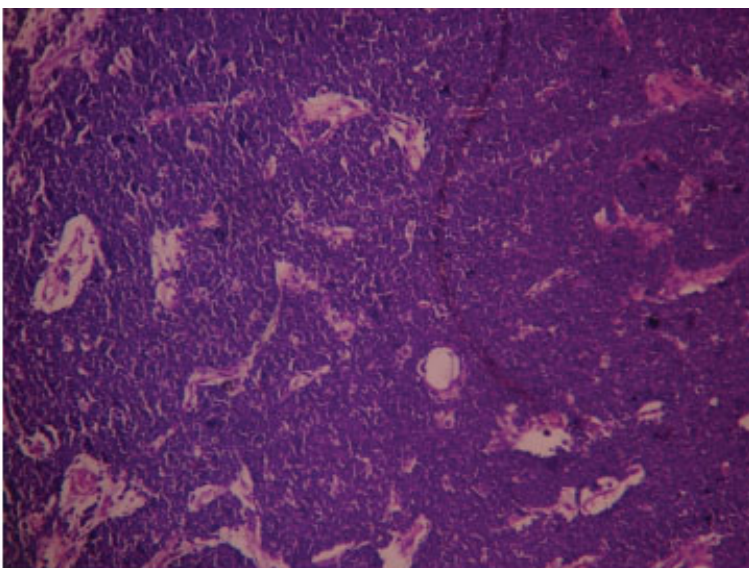

b

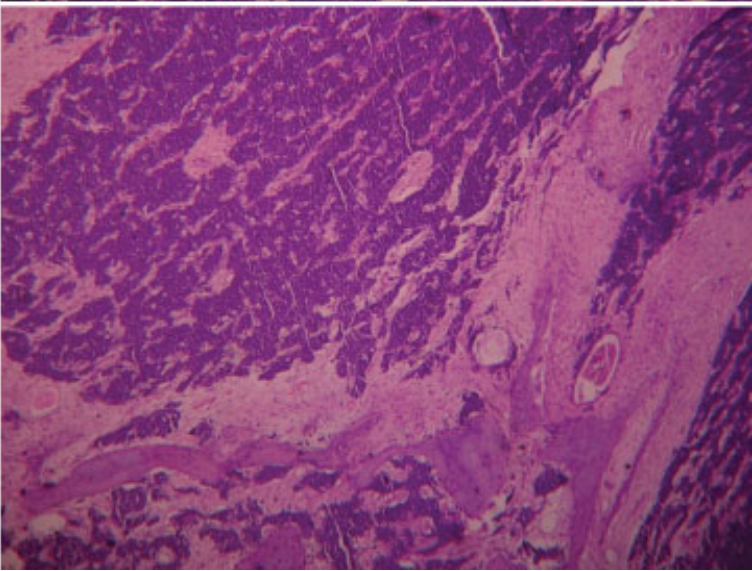

Fig. 11 (A) Small round blue cells. (B) Tumour with collagenous background.

CD 99 positivity and characteristic histopathology confirmed the diagnosis of pPNET/ESFT.

Dural breach and brain parenchymal involvement was present in this patient, which is rarely reported in these type of tumors.

We undertook a neurosurgically and aneasthesiologically challenging combined single-stage surgical approach involving excision of skull and spine lesions with mesh cranioplasty

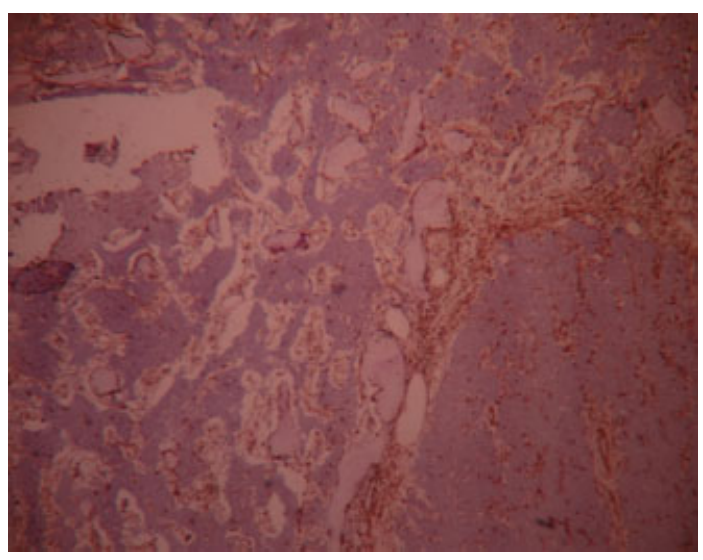

Fig. 12 IHC CD-99 positive.

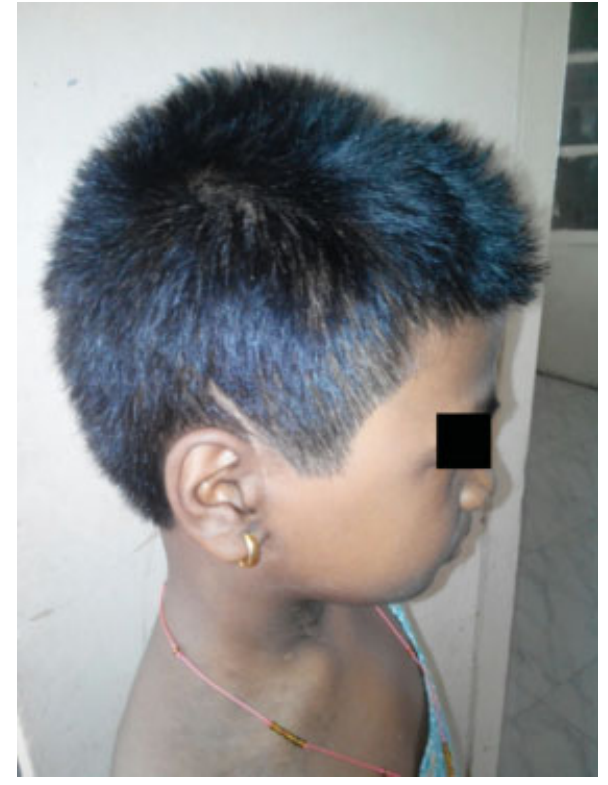

Fig. 13 Six months post-op.

and titanium cage stabilization, which proved beneficial for the patient.

To conclude, ESFT/pPNETs of primary intracranial origin is a neoplasm primarily afflicting children. It is most likely to present as circumscribed, extra-axial masses with or without spinal and distant metastasis. Gross total excision of the tumor should be the immediate goal of the treatment followed by chemotherapy and radiotherapy. A complete screening including radioisotope uptake studies is necessary to rule out the recurrences and prove complete remission of the lesions. Long term survival is better for ESFTs compared with the cPNETs.. ${ }^{1,2}$

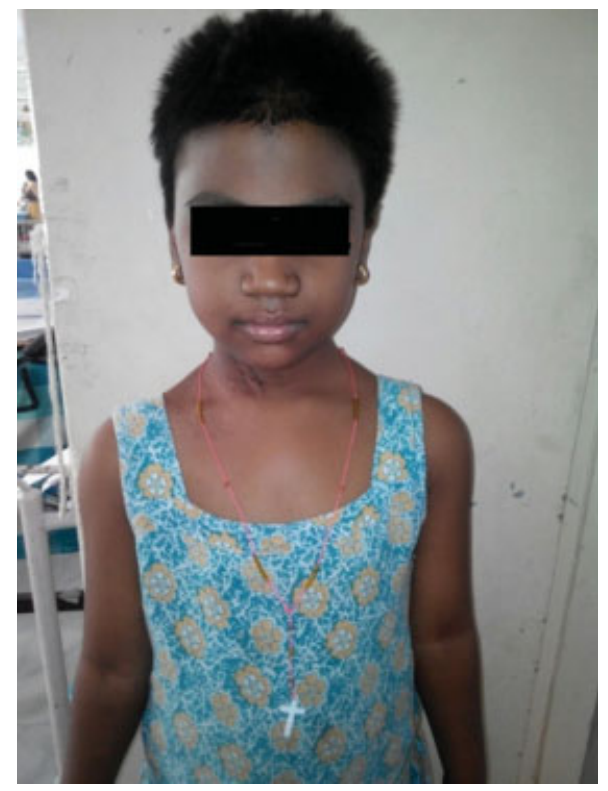

Fig. 14 One year post-op. 

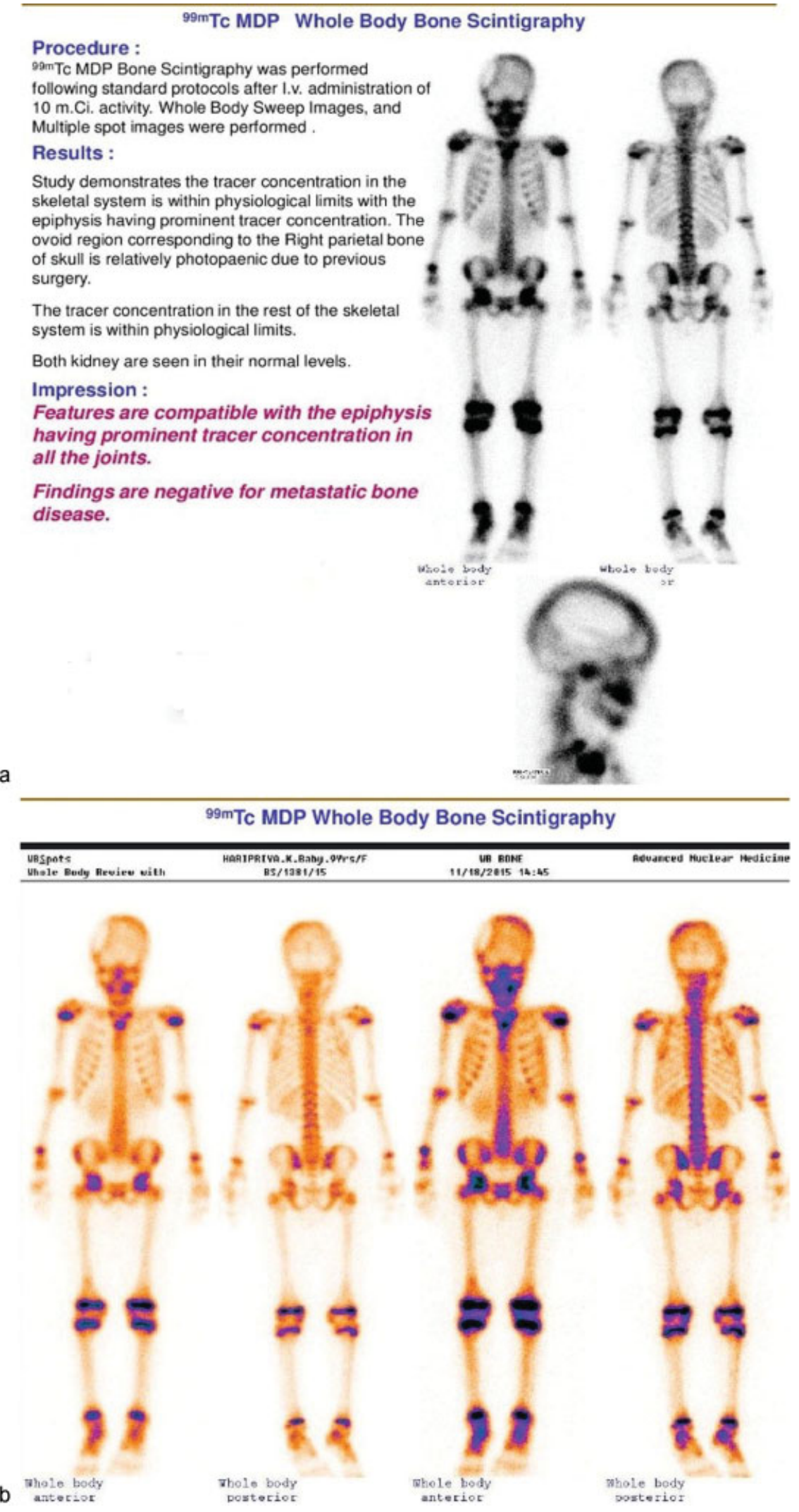

Fig. 15 Radioisotope full body scintigraphy after one year.

We therefore advocate an aggressive approach for both the primary and secondaries, in the form of radical excision followed by implant fixation, such as titanium mesh cranio- plasty and spinal cage fixation, done as a single stage procedure which may augment the recovery and reduce postoperative mortality and morbidity. 


\section{References}

1 Amita R, Sandhyamani S, Nair S, Kapilamoorthy TR. Intracranial ewings sarcoma/peripheral primitive neuroectodermal tumor. Neurol India 2014;62(4):432-433

2 Mobley BC, Roulston D, Shah GV, Bijwaard KE, McKeever PE. Peripheral primitive neuroectodermal tumor/Ewing's sarcoma of the craniospinal vault: case reports and review. Hum Pathol 2006;37(7):845-853
3 Tsokos M. Peripheral primitive neuroectodermal tumors. Diagnosis, classification, and prognosis. Perspect Pediatr Pathol 1992; 16:27-98

4 Louis DN, Ohgaki H, Wiestler OD, et al. The 2007 WHO classification of tumours of the central nervous system. Acta Neuropathol 2007;114(2):97-109 